\title{
MMR
}

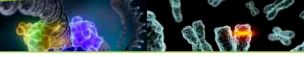

\section{Association of vitamin D receptor gene polymorphisms with end-stage renal disease and the development of high-turnover renal osteodystrophy in a Chinese population}

\author{
L.Y. Wang ${ }^{1 *}$, P. Zhang ${ }^{2 *}$, H.F. Wang ${ }^{3}$, Z.W. Qin ${ }^{2}$, K.B. Wei ${ }^{2}$ and X.A. Lv ${ }^{1}$ \\ ${ }^{1}$ Department of Nephrology, Tai'an City Central Hospital, Tai'an City, \\ Shandong Province, China \\ 2Department of Orthopedics, Tai'an City Central Hospital, Tai'an City, \\ Shandong Province, China \\ ${ }^{3}$ Department of Orthopedics, \\ Laigang Hospital Affiliated to Taishan Medical University, Laiwu City, \\ Shandong Province, China \\ *These authors contributed equally to this study. \\ Corresponding author: X.A. Lv \\ E-mail: xailvta@163.com \\ Genet. Mol. Res. 15 (2): gmr.15026825 \\ Received May 20, 2015 \\ Accepted August 7, 2015 \\ Published June 17, 2016 \\ DOI http://dx.doi.org/10.4238/gmr.15026825
}

\begin{abstract}
Two single nucleotide polymorphisms (SNPs; TaqI and ApaI) in the vitamin D receptor (VDR) gene have been identified as risk factors for the progression of end-stage renal disease (ESRD). The purpose of our study was to confirm the reported association of these two SNPs with ESRD risk and progression of renal osteodystrophy in a Chinese Han population. A total of 452 ESRD patients and 904 matched-pair controls (based on age, gender, and body mass index) were included. Identification of VDR gene polymorphisms was performed using the polymerase chain reaction-restriction fragment length polymorphism method with TaqI and ApaI restriction enzymes.
\end{abstract}


There was no association of the TaqI polymorphism with ESRD risk. However, significant associations were seen between ApaI (rs7975232) polymorphism and ESRD risk in the heterozygote model $(\mathrm{AC} / \mathrm{AA} ; \mathrm{P}=$ $0.002 ; \mathrm{OR}=1.4,95 \% \mathrm{CI}=1.14-1.83)$, homozygote model $(\mathrm{CC} / \mathrm{AA} ; \mathrm{P}=$ $0.007 ; \mathrm{OR}=1.8,95 \% \mathrm{CI}=1.17-2.85)$ genotypes for rs 7975232, allelic model $(\mathrm{P}<0.001 ; \mathrm{OR}=1.4,95 \% \mathrm{CI}=1.15-1.64)$, dominant model $(\mathrm{P}=$ $0.001 ; \mathrm{OR}=1.5,95 \% \mathrm{CI}=1.19-1.87)$, and recessive model $(\mathrm{P}=0.046$; $\mathrm{OR}=0.6,95 \% \mathrm{CI}=0.42-1.00)$ between cases and healthy controls Moreover, we found a significant correlation between the genotype and allele distribution of ApaI and intact parathyroid hormone (iPTH) levels, where allele $\mathrm{C}$ carriers have increased iPTH levels. The ApaI polymorphism in the VDR gene appears to be a susceptibility locus for ESRD in Chinese individuals, and allele $\mathrm{C}$ carriers may have an increased risk of high-turnover renal osteodystrophy.

Key words: ApaI; TaqI; End-stage renal disease; Polymorphism; Renal osteodystrophy

\section{INTRODUCTION}

Chronic kidney disease (CKD) is an important public health problem with a worldwide incidence of $10 \%$ (Sarnak et al., 2003). CKD can lead to decreased life expectancy and quality of life and to enormous costs for patients and health systems (Meguid El Nahas and Bello, 2005). End-stage renal disease (ESRD) is the partial or total loss of kidney function (Duseja et al., 2012). It is well recognized that CKD leading to ESRD is caused by complex pathogenic mechanisms that result from the interactions between multiple genes and environmental factors (Adler, 2006; Böger and Heid, 2011; Dwivedi et al., 2011). Due to the difficulty in stabilizing the disease, patients often develop various abnormalities in bone and mineral metabolism, which significantly increases morbidity and mortality (Erturk and DialGene Consortium, 2006). Therefore, the determination of causative genes leading to ESRD predisposition and its subsidiary complications could provide a better understanding for the pathogenesis of the disease and ensure optimal diagnosis and treatment.

Numerous studies have demonstrated that genetic factors are involved in the onset of ESRD (Borkar et al., 2011; George and Mittal, 2011; Prakash et al., 2012). As a disorder that impairs all metabolic processes associated with vitamin D, ESRD is unsurprisingly associated with vitamin D deficiency (Dusilová Sulková, 2012), which can lead to a series of complications in patients with renal disease. Hence, vitamin D supplementation is usually applied as an adjunct therapy in patients with renal disease, including ESRD (Dusilová Sulková, 2012). The functions of vitamin D in the body are initially mediated by vitamin D receptors (VDRs) (Gross et al., 1998) and clinical studies have reported a better prognosis in ESRD patients treated with VDR activators (Dusilová Sulková, 2012).

The VDR gene is mapped on chromosome 12q12-14 and consists of 11 exons, spanning 63,495 bp (Morrison et al., 1994). VDR has previously been investigated as a candidate gene involved in $\mathrm{CKD}$ risk. Non- $\mathrm{BB}(\mathrm{Bb}+\mathrm{bb})$ variants of the VDR BsmI gene polymorphism are reported to be associated with a higher risk of developing hypercalcemia in peritoneal dialysis patients (Akcay et al., 2005). Two other single nucleotide polymorphisms (SNPs), rs731236 (TaqI) and rs7975232 (ApaI), in the VDR gene have also been identified as risk factors in the 
progression of CKD. However, the results remain controversial among the reported studies, and the effect of these SNPs in the VDR gene on ESRD risk in the Chinese population remains unclear (Fernández et al., 1997; Wang et al., 2004; El-Shehaby et al., 2013). Furthermore, vitamin $\mathrm{D}$ and its receptor have important roles in determining calcium-regulated parathyroid hormone (PTH) secretion (Brown et al., 1982). Few studies have reported the association of genetic variants of the VDR gene with the development of renal osteodystrophy (RO) in patients with ESRD. Therefore, the purpose of this study was to investigate whether two SNPs in the VDR gene (TaqI and ApaI) are associated with ESRD risk and RO progression.

\section{MATERIAL AND METHODS}

The study protocol was approved by the review board of Tai'an City Central Hospital (China) and informed consent was obtained from each participant. A total of 452 Chinese hemodialysis patients (248 males and 204 females) with ESRD were enrolled from our hospital between January 2001 and December 2014. Patients were undergoing hemodialysis for periods ranging from 6 to 276 months ( $79 \pm 68$ months). Patients took calcium carbonate to retain a serum phosphorus concentration of less than $6 \mathrm{mg} / \mathrm{dL}$, and calcitriol or alphacalcidiol unless their serum calcium levels exceeded $11 \mathrm{mg} / \mathrm{dL}$. Patients with liver disease or overt infections were excluded from the study based on their serum gamma glutamyl transferase (GGT) activity. All female patients were not pregnant. A 1:2 matched-pair control group included a total of 904 healthy individuals based on age, gender, and body mass index (BMI). These individuals were selected from those who requested general health examinations in the same hospital during the same period. Demographics of all subjects were collected from a questionnaire survey or medical records. These data included age, gender, BMI, blood pressure, blood biochemical markers [e.g., intact PTH (iPTH), triglycerides], and diabetes.

\section{Blood sampling}

A fasting blood sample was obtained from each patient mid-week on a non-dialysis day. Approximately $10 \mathrm{~mL}$ of venous blood was collected from each participant for DNA extraction and analysis of iPTH, vitamin $\mathrm{D}\left[1,25(\mathrm{OH})_{2} \mathrm{D} 3\right]$, calcium, phosphate, creatinine, blood urea nitrogen, low-density lipoprotein (LDL) cholesterol, high-density lipoprotein (HDL) cholesterol, triglycerides, and albumin. All samples were stored at $-20^{\circ} \mathrm{C}$ until analysis .

Serum iPTH levels were determined using a two-site chemiluminometric assay (Magic Lite iPTH immunoassay, Ciba-Corning Diagnostics Corp., Medfield, MA, USA). Serum vitamin D levels were measured using a commercial competitive protein-binding assay with automated chemiluminescence.

\section{Genotyping}

Genomic DNA was extracted from the whole blood samples using a DNA extraction kit (QIAamp DNA mini Kit, Qiagen, Hilden, Germany). All PCR primers were designed based on sequences previously published (Narooie-Nejad et al., 2015). The TaqI and ApaI polymorphisms were verified by the polymerase chain reaction-restriction fragment length polymorphism (PCR-RFLP) technique. The primers sequences were as follows: TaqI, 5'-GGGACGAT GAGGGATGGACAGAGC-3' (forward) and 5'-GGAAAGGGGTTAGGTTGGACAGGA-3' 
(reverse); and ApaI, 5'-AGAGCATGGACAGGGAGCAAGGCCAGGCAG-3' (forward) and 5'-GCGCAGGTCGGCTAGCTTCTGGATCATC-3' (reverse). The annealing temperatures for ApaI and TaqI SNP were $68^{\circ}$ and $65^{\circ} \mathrm{C}$, respectively. The two SNPs were distinguished by digestion with the $A p a \mathrm{I}$ and TaqI restriction enzymes. Approximately $10 \%$ of the samples analyzed were duplicated to confirm genotyping quality.

\section{Statistical analysis}

All statistical analyses were performed by using the statistical software SPSS 18 (SPSS, Chicago, IL, USA). The distribution of genotypes and alleles in healthy controls was assessed for deviation from Hardy-Weinberg equilibrium. Differences in genotype and allele distribution between patients and controls were analyzed using independent sample $t$-test and $\chi^{2}$ test. The $\mathrm{OR}$ and $95 \% \mathrm{CI}$ were also estimated. A P value $<0.05$ was considered statistically significant.

\section{RESULTS}

For this study, we recruited 452 ESRD patients with a mean age of $58.2 \pm 10.3$ years and 904 unrelated healthy controls with a mean age of $57.9 \pm 10.2$ years. Forty-three ESRD patients had non-insulin-dependent diabetes mellitus and 312 had hypertension. All clinicopathological features of patients are displayed in Table 1. Genotype frequencies for TaqI and ApaI polymorphisms were in keeping with the Hardy-Weinberg equilibrium $(\mathrm{P}>0.05)$.

Table 1. Demographics of ESRD patients included in the study.

\begin{tabular}{l|c}
\hline Variables & ESRD cases $(\mathrm{N}=452)$ \\
\hline Age $($ years $)$ & $58.2 \pm 10.3$ \\
\hline Gender $(\mathrm{M} / \mathrm{F})$ & $248 / 204$ \\
\hline BMI & $26.3 \pm 3.81$ \\
\hline Hypertension & $312(69.0 \%)$ \\
\hline Diabetes mellitus & $97(21.5 \%)$ \\
\hline LDL cholesterol $(\mathrm{mM})$ & $2.8 \pm 1.44$ \\
\hline HDL cholesterol $(\mathrm{mM})$ & $1.2 \pm 0.65$ \\
\hline Triglyceride $(\mathrm{mM})$ & $2.4 \pm 1.41$ \\
\hline Blood urea nitrogen $(\mathrm{mM})$ & $7.7 \pm 4.54$ \\
\hline Serum creatinine $(\mu \mathrm{M})$ & $152.9 \pm 162.92$ \\
\hline Plasma calcium $(\mathrm{mM})$ & $2.7 \pm 0.21$ \\
\hline Serum phosphate $(\mathrm{mM})$ & $1.7 \pm 0.09$ \\
\hline Serum albumin $(\mathrm{g} / \mathrm{L})$ & $41 \pm 6$ \\
\hline Serum $1,25(\mathrm{OH}) 2 \mathrm{D} 3(\mathrm{ng} / \mathrm{mL})$ & $15 \pm 2.91$ \\
\hline Serum $\mathrm{PTH}(\mathrm{pg} / \mathrm{mL})$ & $49.4 \pm 42$ \\
\hline
\end{tabular}

$\mathrm{M}=$ male $\mathrm{F}=$ female; $\mathrm{BMI}=$ body mass index $\mathrm{LDL}=$ low-density lipoprotein $\mathrm{HDL}=$ high-density lipoprotein; $\mathrm{iPTH}=$ intact parathyroid hormone.

As shown in Table 2, the allele and genotype frequencies of VDR SNPs (TaqI and ApaI) in ESRD patients were examined. When the TaqI TT homozygous genotype is used as the reference group, no associations were observed between ESRD risk and the CC and TC genotypes. Similarly, we found no associations between ESRD risk and allelic, dominant, or recessive models. For the ApaI SNP, there was a positive correlation between ESRD risk and the $\mathrm{AC}(\mathrm{P}=0.002 ; \mathrm{OR}=1.4,95 \% \mathrm{CI}=1.14-1.83)$ and $\mathrm{CC}(\mathrm{P}=0.007 ; \mathrm{OR}=1.8,95 \% \mathrm{CI}=$ 1.17-2.85) genotypes when the AA genotype is used as the reference group. In addition, the frequency of the $\mathrm{C}$ allele of the $A p a \mathrm{I}$ polymorphism was significantly higher in ESRD patients than in healthy controls $(\mathrm{P}<0.001 ; \mathrm{OR}=1.4,95 \% \mathrm{CI}=1.15-1.64)$. Furthermore, we found 
a significant difference in dominant $(\mathrm{P}=0.001 ; \mathrm{OR}=1.5,95 \% \mathrm{CI}=1.19-1.87)$ and recessive $(\mathrm{P}=0.046 ; \mathrm{OR}=0.6,95 \% \mathrm{CI}=0.42-1.00)$ models between $\mathrm{ESRD}$ cases and healthy controls.

Table 2. Distribution of genotypes and alleles of the VDR polymorphisms in patients with ESRD and healthy controls.

\begin{tabular}{|c|c|c|c|c|}
\hline & $\operatorname{ESRD}(\mathrm{N}=452)$ & Control $(\mathrm{N}=904)$ & OR $(95 \% \mathrm{CI})$ & P value \\
\hline \multicolumn{5}{|l|}{ TaqI } \\
\hline \multicolumn{5}{|c|}{ Genotypic model: } \\
\hline TT & $215(47.6 \%)$ & $474(52.4 \%)$ & 1.00 & Reference \\
\hline $\mathrm{TC}$ & $197(43.6 \%)$ & $358(39.6 \%)$ & $1.2(0.96-1.54)$ & 0.110 \\
\hline $\mathrm{CC}$ & $40(8.8 \%)$ & $72(8.0 \%)$ & $1.2(0.81-1.86)$ & 0.342 \\
\hline \multicolumn{5}{|c|}{ Allelic model: } \\
\hline $\mathrm{T}$ & $627(69.4 \%)$ & $1306(72.2 \%)$ & 1.00 & Reference \\
\hline $\mathrm{C}$ & $277(30.6 \%)$ & $502(27.8 \%)$ & $1.1(0.96-1.37)$ & 0.119 \\
\hline \multicolumn{5}{|c|}{ Dominant model: } \\
\hline TT & 215 & 474 & 1.00 & Reference \\
\hline $\mathrm{TC}+\mathrm{CC}$ & 237 & 430 & $1.2(0.97-1.52)$ & 0.091 \\
\hline \multicolumn{5}{|c|}{ Recessive model: } \\
\hline $\mathrm{CC}$ & 40 & 72 & 1.00 & Reference \\
\hline $\mathrm{TC}+\mathrm{TT}$ & 412 & 832 & $0.9(0.60-1.34)$ & 0.577 \\
\hline \multicolumn{5}{|l|}{ ApaI } \\
\hline \multicolumn{5}{|c|}{ Genotypic model: } \\
\hline AA & $206(45.6 \%)$ & $502(55.5 \%)$ & 1.00 & Reference \\
\hline $\mathrm{AC}$ & $207(45.8 \%)$ & $350(38.7 \%)$ & $1.4(1.14-1.83)$ & 0.002 \\
\hline $\mathrm{CC}$ & $39(8.6 \%)$ & $52(5.8 \%)$ & $1.8(1.17-2.85)$ & 0.007 \\
\hline \multicolumn{5}{|c|}{ Allelic model: } \\
\hline A & $619(68.5 \%)$ & $1354(74.9 \%)$ & 1.00 & Reference \\
\hline $\mathrm{C}$ & $285(31.5 \%)$ & $454(25.1 \%)$ & $1.4(1.15-1.64)$ & $<0.001$ \\
\hline \multicolumn{5}{|c|}{ Dominant model: } \\
\hline AA & 206 & 502 & 1.00 & Reference \\
\hline $\mathrm{AC}+\mathrm{CC}$ & 246 & 402 & $1.5(1.19-1.87)$ & 0.001 \\
\hline \multicolumn{5}{|c|}{ Recessive model: } \\
\hline $\mathrm{CC}$ & 39 & 52 & 1.00 & Reference \\
\hline $\mathrm{AA}+\mathrm{AC}$ & 413 & 852 & $0.6(0.42-1.00)$ & 0.046 \\
\hline
\end{tabular}

Subsequently, we investigated the relationship between the distribution of the ApaI polymorphism and clinicopathological features in ESRD patients (Table 3). We only found a significant correlation between the ApaI genotype or allele distributions and serum iPTH levels. On the basis of their median serum iPTH levels, these 452 patients were divided into two groups (low and high iPTH). Further analysis revealed that carriers of the $\mathrm{C}$ allele have increased levels of iPTH $(\mathrm{P}=0.005)$.

Table 3. Distribution of genotypes and alleles of the ApaI SNP in the VDR gene in relation to clinicopathological features of ESRD patients.

\begin{tabular}{l|c|c|c|c|c|c|c}
\hline Variables & $\mathrm{AA}(\mathrm{N}=206)$ & $\mathrm{AC}(\mathrm{N}=207)$ & $\mathrm{CC}(\mathrm{N}=39)$ & $\mathrm{P}$ value & $\mathrm{A}(\mathrm{N}=619)$ & $\mathrm{C}(\mathrm{N}=285)$ & $\mathrm{P}$ value \\
\hline Age $(<55 / \geq 55)$ & $90 / 116$ & $98 / 109$ & $24 / 15$ & 0.089 & $278 / 341$ & $146 / 139$ & 0.077 \\
\hline Gender $(\mathrm{M} / \mathrm{F})$ & $102 / 103$ & $113 / 94$ & $25 / 14$ & 0.105 & $317 / 302$ & $163 / 122$ & 0.094 \\
\hline BMI & $26.3 \pm 3.79$ & $26.7 \pm 3.84$ & $26.8 \pm 4.13$ & 0.525 & $26.4 \pm 3.81$ & $26.9 \pm 3.98$ & 0.317 \\
\hline Hypertension $(\mathrm{Y} / \mathrm{N})$ & $92 / 114$ & $100 / 107$ & $20 / 19$ & 0.468 & $284 / 335$ & $140 / 145$ & 0.364 \\
\hline Diabetes mellitus $(\mathrm{Y} / \mathrm{N})$ & $45 / 161$ & $42 / 165$ & $10 / 29$ & 0.793 & $132 / 487$ & $62 / 223$ & 0.884 \\
\hline LDL cholesterol $(\mathrm{mM})$ & $2.7 \pm 1.43$ & $2.9 \pm 1.52$ & $2.9 \pm 1.62$ & 0.481 & $2.7 \pm 1.53$ & $2.9 \pm 1.72$ & 0.248 \\
\hline HDL cholesterol $(\mathrm{mM})$ & $1.4 \pm 0.55$ & $1.3 \pm 0.43$ & $1.2 \pm 0.49$ & 0.328 & $1.4 \pm 0.58$ & $1.2 \pm 0.39$ & 0.334 \\
\hline Triglyceride $(\mathrm{mM})$ & $2.3 \pm 1.52$ & $2.5 \pm 1.43$ & $2.6 \pm 1.66$ & 0.587 & $2.4 \pm 1.59$ & $2.5 \pm 1.62$ & 0.493 \\
\hline Blood urea nitrogen $(\mathrm{mM})$ & $7.5 \pm 4.34$ & $7.7 \pm 4.58$ & $7.9 \pm 4.61$ & 0.283 & $7.6 \pm 4.41$ & $7.8 \pm 4.66$ & 0.145 \\
\hline Serum creatinine $(\mu \mathrm{M})$ & $149.2 \pm 159.29$ & $153.1 \pm 161.87$ & $153.9 \pm 164.47$ & 0.102 & $151.6 \pm 161.62$ & $154.1 \pm 164.12$ & 0.083 \\
\hline Plasma calcium $(\mathrm{mM})$ & $2.5 \pm 0.19$ & $2.7 \pm 0.21$ & $2.8 \pm 0.23$ & 0.101 & $2.6 \pm 0.19$ & $2.9 \pm 0.22$ & 0.095 \\
\hline Serum phosphate $(\mathrm{mM})$ & $1.9 \pm 0.09$ & $1.8 \pm 0.06$ & $1.6 \pm 0.11$ & 0.113 & $1.9 \pm 0.08$ & $1.7 \pm 0.13$ & 0.104 \\
\hline Serum albumin $(\mathrm{g} / \mathrm{L})$ & $40 \pm 5$ & $42 \pm 7$ & $43 \pm 6$ & 0.426 & $40 \pm 8$ & $43 \pm 5$ & 0.378 \\
\hline Serum 1,25(OH)2D3 $(\mathrm{ng} / \mathrm{mL})$ & $16 \pm 2.91$ & $14 \pm 2.89$ & $14 \pm 2.95$ & 0.221 & $15 \pm 2.93$ & $14 \pm 3.12$ & 0.203 \\
\hline Serum $\mathrm{PTTH}(<42 / \geq 42)^{\mathrm{a}}(\mathrm{pg} / \mathrm{mL})$ & $100 / 106$ & $90 / 117$ & $11 / 28$ & $0.038^{*}$ & $290 / 329$ & $112 / 173$ & $0.005^{*}$ \\
\hline
\end{tabular}

$\mathrm{M}=$ male; $\mathrm{F}=$ female; $\mathrm{Y}=$ yes; $\mathrm{N}=$ no. ${ }^{\mathrm{a}} \mathrm{ESRD}$ patients were divided into two groups according to the median value of iPTH levels. ${ }^{*} \mathrm{P}$ value was significant. 


\section{DISCUSSION}

In this study, we investigated the potential effect of two SNPs (TaqI and ApaI) in the VDR gene on ESRD risk and development of RO in a Chinese population. This case-control association study involved 452 patients with ESRD and 904 matched-pair healthy controls. The comparison of genotype and allele distribution between these two groups revealed that the $\mathrm{C}$ allele of the ApaI polymorphism is significantly associated with ESRD risk. This is in accordance with previous findings on the association of VDR polymorphisms with renal function and progression of CKD (Fernández et al., 1997; Cozzolino et al., 2006; Pourfarzam et al., 2014). Moreover, the presence of the $\mathrm{C}$ allele of the ApaI polymorphism may dictate susceptibility for RO.

Vitamin D receptor gene polymorphisms are identified by the presence or absence of a restriction site for the enzymes BsmI, $A p a \mathrm{I}$, and $T a q \mathrm{I}$ at the 3' untranslated region and FoqI at the N-terminal region of the gene by RFLP. VDR gene polymorphisms were initially associated with bone metabolism and prediction for bone mass in subjects without renal disease (Morrison et al., 1994). Since then, several studies have explored the influence of VDR gene polymorphisms on bone and mineral metabolism abnormalities in patients with ESRD. The association of the ApaI polymorphism in the VDR gene with bone and mineral metabolism has been investigated in hemodialysis patients. Yokoyama et al. (1998) reported that serum PTH and osteocalcin levels among patients with the CC genotype were almost twice as high as in patients carrying the A allele. Consistent with their results, our study revealed that the $\mathrm{C}$ allele of the ApaI polymorphism is significantly associated with ESRD risk. In addition, patients carrying the $\mathrm{C}$ allele were more sensitive to changes in serum calcium levels than those with the A allele (Yokoyama et al., 2001). Therefore, the presence of the C allele in the ApaI SNP is a positive indicator for the development of secondary hyperparathyroidism.

In CKD, abnormal calcitriol function and metabolism play a critical role in the development of secondary hyperparathyroidism and RO (Slatopolsky et al., 1999). Several mechanisms associated with an impaired calcitriol/VDR interaction have been identified in CKD. Due to decreased renal mass and serum phosphate retention in ESRD, renal production of calcitriol significantly decreases, and reduced expression of both VDR and the retinoid X receptor has also been found in the kidney and parathyroid gland (Dusso, 2003). The effect of VDR gene polymorphisms on the response of the parathyroid gland to calcitriol has also been investigated (Alvarez-Hernández et al., 2003). High-turnover bone diseases are characterized by rapid bone turnover stimulated by high serum PTH levels and abnormal mineralization. Alvarez-Hernández et al. (2003) reported that the response of the parathyroid glands to calcitriol was not related to VDR gene polymorphisms ApaI or TaqI. However, in our study, we observed that allele $\mathrm{C}$ of the $A p a \mathrm{I}$ polymorphism in the VDR gene was associated with increased iPTH levels, and we concluded that this allele may be indicative of RO. To clarify this, further studies on the influence of VDR genetic variants on RO are needed.

There were several limitations in this case-control study. First, since it is a retrospective case-control study, inherent selection bias cannot be excluded. Second, we did not replicate another investigation in other independent subject panels or in other ethnic groups to confirm the validation of our findings in this study. Furthermore, the sample size in our study was relatively small and therefore some bias is inevitable.

In conclusion, the ApaI polymorphism of the VDR gene may be a susceptibility locus for ESRD in Chinese individuals, and allele $\mathrm{C}$ carriers appear to have an increased risk of RO. 
Genotype determination of these SNPs may be more informative for assessment of the genetic risk of ESRD in Chinese individuals.

\section{Conflicts of interest}

The authors declare no conflict of interest.

\section{REFERENCES}

Adler S (2006). Renal disease: environment, race, or genes? Ethn. Dis. 16: S2-35-39.

Akcay A, Ozdemir FN, Sezer S, Micozkadioglu H, et al. (2005). Association of vitamin D receptor gene polymorphisms with hypercalcemia in peritoneal dialysis patients. Perit. Dial. Int. 25 (Suppl 3): S52-S55.

Alvarez-Hernández D, Naves M, Santamaría I, Menárguez J, et al. (2003). Response of parathyroid glands to calcitriol in culture: Is this response mediated by the genetic polymorphisms in vitamin D receptor? Kidney Int. Suppl. 85: S19-S22. http://dx.doi.org/10.1046/j.1523-1755.63.s85.6.x

Böger CA and Heid IM (2011). Chronic kidney disease: novel insights from genome-wide association studies. Kidney Blood Press. Res. 34: 225-234. http://dx.doi.org/10.1159/000326901

Borkar M, Tripathi G, Sharma RK, Sankhwar SN, et al. (2011). Chemokine (CCR) and fractalkine (CX3CR) receptors and end stage renal disease. Inflamm. Res. 60: 399-407. http://dx.doi.org/10.1007/s00011-010-0284-3

Brown EM, Wilson RE, Eastman RC, Pallotta J, et al. (1982). Abnormal regulation of parathyroid hormone release by calcium in secondary hyperparathyroidism due to chronic renal failure. J. Clin. Endocrinol. Metab. 54: 172-179. http://dx.doi.org/10.1210/jcem-54-1-172

Cozzolino M, Gallieni M, Brancaccio D, Arcidiacono T, et al. (2006). Vitamin D retains an important role in the pathogenesis and management of secondary hyperparathyroidism in chronic renal failure. J. Nephrol. 19: 566-577.

Duseja A, Choudhary NS, Gupta S, Dhiman RK, et al. (2012). Treatment of chronic hepatitis C in end stage renal disease: experience at a tertiary care centre. Trop. Gastroenterol. 33: 189-192. http://dx.doi.org/10.7869/tg.2012.47

Dusilová Sulková S (2012). [Vitamin D metabolism and current options for therapeutic activation of vitamin D receptor in patients with chronic kidney disease or renal failure]. Vnitr. Lek. 58: 839-849.

Dusso AS (2003). Vitamin D receptor: mechanisms for vitamin D resistance in renal failure. Kidney Int. Suppl. 85: S6-S9. http://dx.doi.org/10.1046/j.1523-1755.63.s85.3.x

Dwivedi RS, Herman JG, McCaffrey TA and Raj DS (2011). Beyond genetics: epigenetic code in chronic kidney disease. Kidney Int. 79: 23-32. http://dx.doi.org/10.1038/ki.2010.335

El-Shehaby AM, El-Khatib MM, Marzouk S and Battah AA (2013). Relationship of BsmI polymorphism of vitamin D receptor gene with left ventricular hypertrophy and atherosclerosis in hemodialysis patients. Scand. J. Clin. Lab. Invest. 73: 75-81. http://dx.doi.org/10.3109/00365513.2012.743163

Erturk S; DialGene Consortium (2006). Gene polymorphism association studies in dialysis: bone and mineral metabolism. Semin. Dial. 19: 232-237. http://dx.doi.org/10.1111/j.1525-139X.2006.00160.x

Fernández E, Fibla J, Betriu A, Piulats JM, et al. (1997). Association between vitamin D receptor gene polymorphism and relative hypoparathyroidism in patients with chronic renal failure. J. Am. Soc. Nephrol. 8: 1546-1552.

George GP and Mittal RD (2011). Genetic polymorphisms in MHC-encoded antigen processing gene TAP2: a case-control study in end-stage renal disease patients of North India. Transpl. Immunol. 24: 220-223. http://dx.doi.org/10.1016/j. $\underline{\text { trim.2011.03.003 }}$

Gross C, Krishnan AV, Malloy PJ, Eccleshall TR, et al. (1998). The vitamin D receptor gene start codon polymorphism: a functional analysis of FokI variants. J. Bone Miner. Res. 13: 1691-1699. http://dx.doi.org/10.1359/ jbmr.1998.13.11.1691

Meguid El Nahas A and Bello AK (2005). Chronic kidney disease: the global challenge. Lancet 365: 331-340. http:// dx.doi.org/10.1016/S0140-6736(05)17789-7

Morrison NA, Qi JC, Tokita A, Kelly PJ, et al. (1994). Prediction of bone density from vitamin D receptor alleles. Nature 367: 284-287. http://dx.doi.org/10.1038/367284a0

Narooie-Nejad M, Moossavi M, Torkamanzehi A and Moghtaderi A (2015). Positive association of vitamin D receptor gene variations with multiple sclerosis in South East Iranian population. BioMed Res. Int. 2015: 427519. http:// dx.doi.org/10.1155/2015/427519

Pourfarzam M, Nia KM, Atapour A and Sadeghi HM (2014). The influence of BsmI and TaqI vitamin D receptor gene 
polymorphisms on the intensity of hyperparathyroidism in Iranian hemodialysis patients. Adv. Biomed. Res. 3: 213. http://dx.doi.org/10.4103/2277-9175.143260

Prakash S, Prasad N, Sharma RK, Faridi RM, et al. (2012). Vascular endothelial growth factor gene polymorphisms in North Indian patients with end stage renal disease. Cytokine 58: 261-266. http://dx.doi.org/10.1016/j.cyto.2012.01.020

Sarnak MJ, Levey AS, Schoolwerth AC, Coresh J, et al.; American Heart Association Councils on Kidney in Cardiovascular Disease, High Blood Pressure Research, Clinical Cardiology, and Epidemiology and Prevention (2003). Kidney disease as a risk factor for development of cardiovascular disease: a statement from the American Heart Association Councils on Kidney in Cardiovascular Disease, High Blood Pressure Research, Clinical Cardiology, and Epidemiology and Prevention. Hypertension 42: 1050-1065. http://dx.doi.org/10.1161/01.HYP.0000102971.85504.7c

Slatopolsky E, Brown A and Dusso A (1999). Pathogenesis of secondary hyperparathyroidism. Kidney Int. Suppl. 73: S14-S19. http://dx.doi.org/10.1046/j.1523-1755.1999.07304.x

Wang NN, Wang XY, Peng T, Wu HF, et al. (2004). Expression of the calcium receptor CaR in the parathyroid of secondary hyperparathyroidism patients. Chin. Med. J. (Engl.) 117: 1408-1410.

Yokoyama K, Shigematsu T, Tsukada T, Ogura Y, et al. (1998). Apa I polymorphism in the vitamin D receptor gene may affect the parathyroid response in Japanese with end-stage renal disease. Kidney Int. 53: 454-458. http://dx.doi. org/10.1046/j.1523-1755.1998.00781.x

Yokoyama K, Shigematsu T, Kagami S, Tsukada T, et al. (2001). Vitamin D receptor gene polymorphism detected by digestion with Apa I influences the parathyroid response to extracellular calcium in Japanese chronic dialysis patients. Nephron 89: 315-320. http://dx.doi.org/10.1159/000046092 